\title{
$2 \frac{P}{\frac{P}{S}}$ Porsesh Research \& Studies Organization Research for Informed Decision-making
}

\section{Ignored Identities}

(The Status of Hindus and Sikhs in Afghanistan's Legal System)

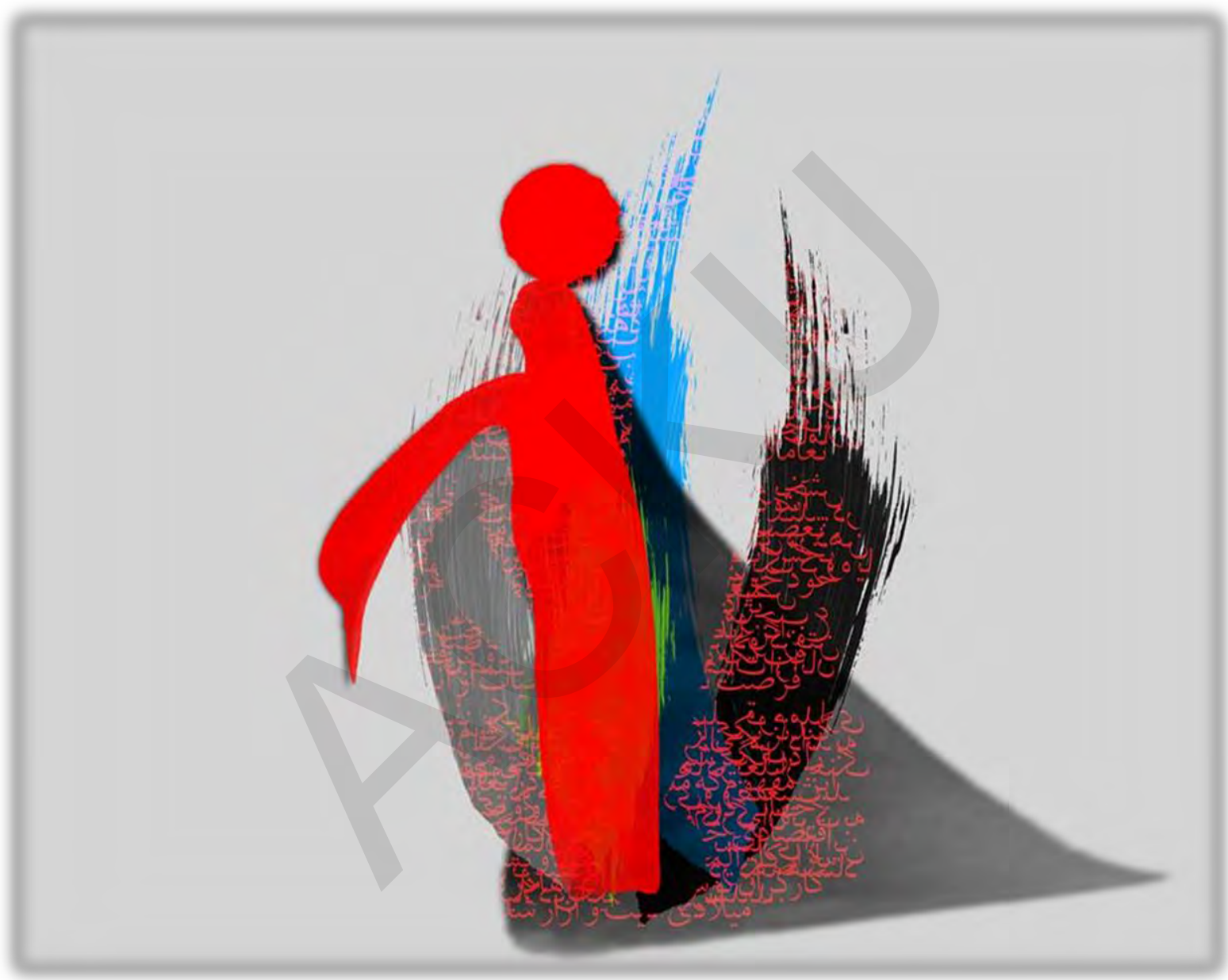

By:

Ehsan Shayegan

Yahya Ammaar

Front Cover Graphic: Hamid Fidel 


\section{Acknowledgement}

Special thanks to Shamsi Maqsudi, university lecturer who conducted the technical review and Benazir Noorzad, PRSO intern, for translating the law from Dari to English. We express our deep gratitude to Ahmad Shah Mubariz, PRSO research board member, for the constructive comments. 


\begin{abstract}
Since 2001 both the Government of Afghanistan and Afghan civil society have claimed that the country's new Constitution and legislative reforms provide a strong base for assuring human rights. However, few voices have raised the issue of the rights of Afghanistan's non-Muslim citizens, which is ignored by the stereotype of equal rights. The issue of the rights of non-Muslim Afghan citizens has never been seriously questioned or examined. There is widespread sentiment that the words "Afghan" and "Muslim" are synonymous, making it difficult for many people to think of an Afghan as anything but Muslim.

This paper examines the rights of non-Muslim Afghan citizens, particularly Hindus and Sikhs, in Afghanistan's legal system through human rights discourse and a comparative examination of Afghanistan's laws on a chronological basis since 1923. This analysis is complemented by a desk review of existing research and literature on the status of Hindus and Sikhs in Afghanistan's legal system.

The authors conclude that Afghanistan's legal system is contradictory, discriminatory and not equal when it comes to civil rights and human rights. Some articles in the Constitution, Civil Law and Criminal Procedure Code sound more like a religious fatwa regarding Hindus and Sikhs. Hindus and Sikhs are marked as "Ignored Identities" who exist but are not considered in the Constitution and other laws, resulting in them being forgotten and excluded from Afghanistan's legal system.
\end{abstract}

Keywords: Human rights discourse, Constitution, law, minorities 


\section{Introduction}

In 1970 Afghanistan was considered a home of Hindu civilization and had thriving Hindu and Sikh populations, estimated to number around 200,000 people (Hafsite.org, 2012). Since that time, the story of Hindus and Sikhs in Afghanistan has followed a different trajectory to other citizens of Afghanistan, as they experienced discrimination as non-Muslim minorities. From the collapse of the communist regime, through civil war and Taliban rule, they experienced a catastrophic era. Many Sikh gurdwaras and Hindu temples were destroyed. They were pressured to convert to Islam, forced to pay a special tax and were socially identified by yellow patches not unlike the Jews in Nazi Germany. It was common for them to be subjected to the forced sale of their lands and properties by the warlords (Bureau of Democracy, Human Rights, and Labor, 2010)

After 11 September, 2001 international forces invaded Afghanistan leading to the Bonn Agreement whereby the Government of Afghanistan agreed to support human rights and the initiation of a commission to prepare the first preliminary draft of a revised Constitution, which was later discussed, amended and adapted at the 2003 Constitutional Loya Jirga.

The Constitution includes a mandate to abide by the Universal Declaration of Human Rights to create a prosperous and progressive society based on social justice, protection of human dignity, protection of human rights, the realization of democracy to ensure national unity and equality among all ethnic groups and tribes (Bureau of Democracy, Human Rights, and Labor, 2011) .

Since the adoption of the new Constitution there have been consistent promises made by Afghan politicians, including former president Hamid Karzai and President Ashraf Ghani, to address the concerns of Afghanistan's Sikh and Hindu communities and ensure that they, like all Afghans, are equally protected by the law.

To understand the legal status of Hindus and Sikhs beyond political promises and propaganda it is necessary to scrutinize the Constitution and other laws. This paper sheds light on the status of non-Muslim Afghan citizens, particularly Hindus and Sikhs, within Afghanistan's legal system. It does so with reference to human rights discourse, the Universal Declaration of Human Rights (UDHR) and other international conventions on human rights. It examines the Constitution and laws of Afghanistan by reference to their historical origin in chronological order, placing the current Constitution and laws at the center of the debate.

The paper begins with a literature review and analysis of major themes such as the political rights of Hindus and Sikhs, common liberties, their rights in the judicial system, personal status and freedom of religion in the Constitution and other laws. It then analyses the position of 
Hindus and Sikhs in Afghanistan's various constitutions and laws from 1923 to the present. The paper concludes that there is still a long way to go before Hindus and Sikhs can truly be considered equal to their fellow Afghan citizens in the legal system.

\section{Literature Review}

The last 15 years have been an exceptional era in Afghanistan's history in terms of production of a large amount of literature on human right issues. However, what has been produced so far is rudimentary with insufficiencies in terms of quality and evidence-based research, making it difficult to rely on for constructive debate.

The literature on the rights of Hindus and Sikhs may be categorized into academic and nonacademic texts covering a miscellaneous range of topics, focuses and approaches. Some have focused to varying extents on legal aspects, minorities and women's rights in the context of Afghanistan's Constitution and laws. For instance, in 2012 the Human Rights Department of the Ministry of Justice highlighted minorities' rights in the Constitution and other laws in a research report entitled Brief report on reflection of Declaration on the Rights of Persons Belonging to National or Ethnic, Religious and Linguistic Minorities in national laws and its implementation in practice (Islamic Republic of Afghanistan Ministry of Justice Chief Office of the Minister Human Rights Support Unit, 2012). The report has a subjective, descriptive and judgmental tone, highlighting the specific articles of laws and the Constitution consistent with human rights values and neglecting those articles which conflict with the UDHR.

The International Religious Freedom Report published by the US State Department's Bureau of Democracy, Human Rights and Labor, particularly those published in 2011, 2012 and 2015, provide annual updates on some of the legal issues facing Hindus and Sikhs, stressing the challenge of freedom of religion. The 2011 report Notes that the new Constitution and other laws of Afghanistan explicitly restrict religious freedom. Article 3 of the Constitution provides that no law can be contrary to Islamic law, while article 2 states that Islam is the religion of the State. This amounts to discrimination based on religious affiliation, belief or practices. Also, it is repeatedly shown that some basic citizenship rights of non-Muslims are not vividly codified. As a result they are treated under Hanafi and Islamic law whereas in practice, courts do not always accord Muslims and non-Muslims equally.

In his article Minorities and marginality: pertinacity of Hindus and Sikhs in a repressive environment in Afghanistan (2013), Hafizullah Emadi documents the marginalized status of Hindus and Sikhs throughout Afghanistan's recent history, describing how Hindus and Sikhs have been engaged in a hard battle to preserve their culture and religious traditions in a hostile political environment. This demonstrates the failure and collapse of moral obligations of the international community and the state in Afghanistan, and their inability to preserve and defend the rights of oppressed minorities such as Hindus and Sikhs. 
Among the vast literature produced on Afghan Hindus and Sikhs, The Implementation of Constitutional Human Rights in Afghanistan (Sadat, 2004) criticizes the biased approach of articles in the Constitution and laws through topics including the drafting of the new Constitution, the Constitutional Loya Jirga, Constitutional debate, human rights provisions and religion and the State, and principally presents a human rights analysis of the new Constitution, exploring potential pitfalls to its implementation. Minorities and women are placed at the core center of the analysis. The author states that:

The state sanctioned discrimination that runs throughout the new Constitution clearly contradicts the commitment to human rights and equal participation included in other provisions of the Constitution, the manner in which state implements the new Constitution will determine which principles will prevail. A look at the judiciary, the main vehicle for implementation, raises genuine concerns about the potential for human rights abuses.

The suppression of Hindus and Sikhs is a structural phenomenon, multilayered in the different folds of law, including the Constitution, degrading equal citizenry rights in the areas of political participation, civil rights, personal status, and the judicial system. The existing literature addresses some legal challenges of Hindus and Sikhs in broken parts without framing them in a broader mechanism or within their proper legal system. Hence, this paper leans on to a more systemized approach, examining Afghanistan's legal system through the Constitution and several key laws.

\section{Theoretical Framework}

Since the second half of the 20th century, human rights have gained critical significance, at least their ethical aspect, at both the national and international level. It is arguably the dominant discourse of our time. Today, any political regime that is not committed to human rights values is considered illegitimate because human rights constitute the parameter of evaluating state legitimacy both domestically and internationally (Habermas, 2001). As a result, most countries have included human rights provisions in their Constitution and are committed to support and respect them.

Human Rights are intrinsic, universal, inalienable, and non-transferable rights that each human being is born with and entitled to, regardless of his or her political, linguistic, racial or gender affiliation. Protection of human rights guarantees a dignified life for human beings whereas violation of such rights endangers humanity.

As a member of the international community, Afghanistan has signed and ratified many protocols and conventions including the Charter of the United Nations, International Covenant on Civil and Political Rights, International Covenant on Economic, Social and Cultural Rights, International Convention on the Elimination of all forms of Racial Discrimination, Convention 
on the Rights of the Child, Convention on the Elimination of all Forms of Discrimination against Women, Slavery Convention, Rome Statute of the International Criminal Court, Convention Concerning Forced or Compulsory Labor, and the Discrimination (Employment and Occupation) Convention, among others (Moj.gov.af, 2016). Most of these conventions have been signed by Afghanistan in the second-half of the $20^{\text {th }}$ Century and the country is required to respect and promote the rights enshrined in these conventions.

\section{Political participation and public liberties}

The current Constitution of Afghanistan commits to a range of internationally recognized human rights conventions, and institutions like the Afghanistan Independent Human Rights Commission, to ensure human rights protection. The preamble, Articles 6 and 7 and the second chapter of the Constitution commit to respecting and promoting the UDHR and affirm a variety of social, political, economic, civil and cultural rights.

Article 7 states that, "the state shall abide by the UN Charter, international treaties and international human rights conventions that Afghanistan has signed and the Universal Declaration of Human Rights". In contrast, much of the Constitution is a combination of civil law and sharia law, containing provisions where Islam plays a dominant role in shaping all spheres of life from education to political parties and judicial interpretation (Sadat, 2004).

The legal system in any country defines the nature of its political system and consequently provides the context of political participation for its citizens. According to the Constitution, Afghanistan appears to have a democratic political system, as citizens elect the executive and legislators. However, deeper observations show structural discrimination against part of the population - Hindus and Sikhs. This systematic discrimination is not a new problem. It has its roots in the country's political history. Afghanistan's first constitution, entitled The Main Code of Afghanistan Great State, enacted in 1924, set the cornerstone for the omission of minority groups like the Hindus and Sikhs from the political arena. Article 4 states that based on the extraordinary services and efforts of the great Humayoun for the development and autonomy of the Afghan nation, they make a commitment to accept the power and kingdom transformation through the King and his descendants (The Afghanistan Constitutions, 2007).

The provisions of this article, in Afghanistan's second constitution, The Fundamental Principles of Afghanistan Great State, enacted in 1930, are repeated in the same way.

It is also stated that the religion of Afghanistan is the sacred religion of Islam, Sharia is based on the Hanafi Recitation of the religion, Other religions, like Hindus and Jews who are in Afghanistan, as long as they do not disrupt a public convenience and customs, will also be taken into consideration. 
Likewise Articles 36 and 37, concerning the oaths taken by members of parliament, demonstrate the monopoly of Islamic thought - there is no alternative oath or affirmation for non-Muslim civilians.

The 1964 Constitution provides that the King shall be a citizen of Afghanistan, a Muslim, and a follower of the Hanafi Sect of Islam. Based on article 64 of the Constitution in Zahir Shah's period, shura were only authorized to make laws within the mechanism of the Constitution which clearly states that no law can be contrary to Islam and other constitutional values.

Article 77 of the 1974 Constitution, enacted during the presidency of Mohammad Daoud Khan, states that the President must be a citizen of Afghanistan and a Muslim, that the King and his wife shall have been born from Afghan parents, they shall have civil and political rights and that the King's age shall not be less than forty years.

Likewise article 92 of 1974 Constitution contains a clear statement on testimonial of the deputy president and minister, making commitment as supportive and on the basis of Islamic religious thoughts, only.

Articles 73 and 74 of the 1987 Constitution also clearly state that every Muslim citizen of Afghanistan who has completed the age of 40, he and his wife should have been born of Afghan parents, and who has civil and political rights, can be selected as the president, and after the election, the following oath shall take place by the president in the Loya Jirga:

In the name of God, I pledge to keep the principles of the sacred religion of Islam, defend the Constitution, assure the implementation of it, and respect liberty, sovereignty and territorial integrity of Afghanistan. I will protect the fundamental rights and freedoms of citizens, and bring social justice, joy for the people, peace and prosperity of my country.

The 2003 Constitution, considered Afghanistan's most democratic Constitution, was developed from three sources: democracy, human rights and Islam. The current Constitution contains many articles that are discriminatory towards Hindus and Sikhs. Article 3 states that no law can be contrary to the beliefs and provisions of the sacred religion of Islam, while Article 35 states that the manifesto and charter of political parties should be consistent with the principles of Islam. Further, article 62 restricts the political participation of non-Muslim Afghan citizens, stipulating that any head of state must be Muslim. The oath of allegiance to God and Islam taken by the president, vice-presidents, ministers, and Supreme Court judges has a clear marginalizing effect (Sadat, 2004).

Article 4 of the current constitution provides that the nation of Afghanistan is comprised of Pashtun, Tajik, Hazara, Uzbek, Turkmen, Baluchi, Pashayi, Nuristani, Aymaq, Arab, Kyrgyz, Qezelbash, Gujar, Barhawi and other ethnicities. There is no mention of Afghanistan's Hindu and Sikh communities. Although the phrase "other ethnicities" is open to interpretation, given that Hindus and Sikhs are well-known communities in Afghanistan they should not have been 
overlooked in what is supposed to be a progressive and inclusive constitution. Turning to political participation, specifically the presidency, article 62 stipulates that a presidential candidate should be a citizen of Afghanistan, Muslim, born of Afghan parents and should not have citizenship of another country. These restrictions also apply to the deputy president. The only difference between the current Constitution and its predecessors is that the conditionality of being a Hanfi follower for the political leadership is lifted, but it is still biased against the nonMuslim citizens of Afghanistan, who can never be president.

Hindus and Sikhs of Afghanistan, have not only faced discrimination and effectively been omitted from political participation, they also lack public liberties. Article 2 of the first Constitution of Afghanistan stated that:

The religion of Afghanistan is the sacred religion of Islam, the official and general school of thought is Hanafi. Followers of other religions, Hindus and Jews, are entitled to the full protection of the state provided they do not disturb the public peace.

According to the article 13 of the first Constitution of Afghanistan, every Afghan citizen, individually or collectively, can file a complaint if they come across any movement or behavior contrary to sharia law and government. They can directly consult the King if any government entity has not addressed their complaint. This article restricted public liberties anywhere in the country, as this article authorized every citizen to monitor and complain of any non-Islamic acts. Therefore, Hindus and Sikhs could only freely perform their religious rites as long as they do not interfere with public peace which is based on the sharia. As, public peace is not defined anywhere, Muslims can create restrictions for Hindus and Sikhs anytime under the pretext of a breach of the peace. Article 15 of the first Constitution does however guarantee the right of access to education for Hindus and Sikhs.

The 1930 Constitution adopts a similar tone to the country's first constitution in respect of the religious freedom and belief of Hindus and Sikhs. Article 1 state that the religion of Afghanistan is the sacred religion of Islam, the official and the dominant fiqha is Hanafi and that the King of Afghanistan should be a follower of this school of thought. The practice of other religions, such as Hinduism and Judaism, will not be interfered with as long as it does not disrupt the public convenience and customs. This procedure continued until the reign of Mohammad Zahir Shah.

Article 2 of the 1964 Constitution stipulated that:

The religion of Afghanistan is the sacred religion of Islam. Religious rituals are decided by the government in accordance with the provisions of the Hanafi school of thought. Citizens who do not follow the religion of Islam, are free practice their faith and religious ceremonies within the framework of the laws relating to customs and public security and customs. 
The provisions of this article are repeated in the form of various statements in the 1976 and 1987 constitutions that were enacted during the presidency of Dawood Khan and the communist regime.

The current Constitution, as the mother of all other legislation, is excessively dependent upon Islamic interpretations. Articles 130 and 131 call for the development of Sunni and Shia Islamic jurisprudence in the absence of existing laws or cases dealing with personal status. Failure to define and interpret the Islamic provisions on the basis of legal parameters is a major challenge. Obviously the subjective applications of the sharia based laws have negative implications for the protection and promotion of human rights because such law excludes others and paves the way for any kind of interpretations and interventions against non-Muslim citizens (Sadat, 2004).

As per the 2004 Constitution, the State is responsible for the design and implementation of a unified education curriculum, but one based on Islamic provisions, national culture, and religious subjects designed on the basis of the existing Islamic sects in Afghanistan. Currently, Islamic thought prevails in the content of public school curriculum and there is no provision to include content from other religious groups (Bureau of Democracy, Human Rights, and Labor, 2012).

Similarly, Article 45 declares that educational curricula must be, in part, based on the provisions of Islam. In addition, Article 54 calls for the elimination of all traditions contrary to Islamic principles. Articles 19 and 20 prescribe components of Islamic wording and symbols in the national flag and national anthem. More strongly, Article 149 states that the provisions of adherence to the fundamentals of the sacred religion of Islam and the regime of the Islamic Republic cannot be subject to amendment (Sadat, 2004).

\section{Personal Status and Freedom of Religion}

Afghanistan's civil law, which regulates the private life and transactions of citizens, has been developed on the basis of Islamic law. Therefore, non-Muslims are left out of the circle. Paragraph 2 of Article 1 of the Civil Law states that, in cases where there is no law, the court will use the general principles of Hanafi Islamic jurisprudence to attain justice in the best manner possible. Article 2 states that in cases where general principles of Islamic Hanafi law jurisprudence does not exist, the court will issue a judgment in accordance with common practice provided this practice is not contrary to the provisions of law or the principles of justice. This happens despite the fact that Hindus and Sikhs do not have a personal status law to conform with in order to settle family matters (Ministry of Justice, 1976).

Article 130 of the Constitution provides that when dealing with cases, judges are to apply the provisions of the Constitution and other laws. Where there is a gap in the Constitution or other laws, the court is to follow Hanafi jurisprudence within the framework of the Constitution to resolve the matter in a way that attains justice in the best manner. Article 131 provides that for matters relating to the personal status of the Shia community, the law is implemented by 
adherence to Shiite jurisprudence. Previous constitutions also directed the filling of gaps in the law with religious interpretation. Article 102 of the 1964 Constitution gave free hand to acts based on Hanafi sharia law where there is not a particular legal order. The same thing was repeated in article 99 of the 1976 Constitution and in article 112 of the 1987 Constitution, both provisions stating that in absence of law, cases should be solved on the basis of sharia law (The Afghanistan Constitutions, 2007).

Islamic interpretation is common within the judiciary. Article 121 of the enacted Constitution authorizes the Supreme Court to review laws, legislative decrease, international treaties, and international conventions and interpret them in accordance with the Constitution dominated by the Islamic thought as the supreme law of the land (Sadat,2004). Also, under the penal code, religious minorities are subject to Islamic law in situations where there is no specific provision in the Constitution or penal code (Hafsite.org, 2012).

These are statutory examples of the radicalized social and legal discrimination toward nonMuslim citizens in Afghanistan. Much discrimination also exists in society where Hindus and Sikhs face violence in the public space during their cultural and social gatherings, even in the case of their funerals. "They throw stones and bricks at us, at the bodies of the dead, whenever there is a funeral", said Avtar Singh, pointing to a newly built house next to the crematorium". likewise, in a very recent case of "a bright day in downtown Kabul, Jagtar Singh Laghmani was in his traditional herb shop when a man turned up, drew a knife and told him to convert to Islam or he would cut his throat. Only bystanders and other shopkeepers saved his life"(Reuters, 2016).

Referring to law, the Constitution and penal code are silent on apostasy and blasphemy, which gives free hand to the courts, relying on their interpretation of Sharia Law, to punish alleged offences, even where this violates the country's international commitments to the UDHR and the International Covenant on Civil and Political Rights (Pike, 2012).

Afghanistan's Constitution fails to protect the individual's right to freedom of religion or belief, as do other laws that contradict international human rights standards. In some cases the Taliban regime and internationally backed post-Taliban government have taken similar actions against "un-Islamic" activity (USCIRF, 2014).

Afghanistan still remains at the top of the list of nations with a very poor record on religious freedom. There is strong evidence showing intolerance throughout the country on the part of government agencies, groups and individuals toward what is perceived as "un-Islamic" conduct by non-Muslim civilians. This intolerance is supported by a strong legal base institutionalizing social intolerance on the basis of a vague legal framework that gives free hand to Afghanistan's government to limit the fundamental rights and freedoms of its citizens (Swett and Leo, 2012). 


\section{Judicial Affairs}

Article 119 of the 2004 Constitution providers that members of the Supreme Court, before the occupation of duty, take the oath before to the president - an oath that is almost akin to a religious statement (The Afghanistan Constitutions, 2007). Similarly, article 59 of the Law on Structure and Authority of the Judicial Body of Afghanistan, under condition of court, amplifies that before the occupation of their duty, the judge pledges the oath in the presence of the Chairman and members of the Supreme Court to respect and implement Islamic law, the Constitution and laws of the country (Ministry of Justice, 2005). These two articles benefit only the Muslim members of the Supreme Court and other courts and effectively make the implementation of Islam their legal responsibility.

Afghanistan's laws for witnesses include a series of conditions that have to be met by them during their testimony. Article 234 of the Criminal Procedure Code of 1965 states that those who have not completed their fourteenth year of age are required to swear to Allah before the testimony to perform only the right and not to perform other than the right (Ministry of Justice, 1965). Similar provisions existed in Article 50 of the Temporary Criminal Procedure Code (2003) and Article 36 of the Military Criminal Procedure Code (2010). However, this issue appears to have been addressed as article 43 of the revised and newly enacted Criminal Procedure Code states that if the witness is a non-Muslim, they should swear on their own Holy book and perform the testimony (Ministry of Justice, 2014). In situations where the Constitution and penal code are silent, including on apostasy and blasphemy, courts rely on their own interpretations of Islamic law, under Article 130, that may be contrary to the country's international commitments to the Universal Declaration of Human Rights and the International Covenant on Civil and Political Rights (Pike, 2012). 


\section{Conclusion}

There appears to be great inequality in the Afghan legal system's treatment of Muslims on the one hand and Hindus as Sikhs on the other, as evidenced by the way their rights and freedoms and subordinated in the Constitution and key laws.

In reviewing Afghanistan's constitutions and laws, it is apparent that there exists a sense of "otherness" and a harsh differentiation that relegates Hindus and Sikh to the role of second class citizens. Even though Afghanistan has committed to the realization of human rights, respect and dignity since its 1964 Constitution, that commitment is persistently undermined by the discriminatory approach of the legal system to non-Muslim citizens. Commitments of Afghanistan Government and abiding to respecting and protecting of human rights values initially collapsed and fail within law and legal system. Afghanistan's legal system is a composite of several contradictions of human rights and Islamic values, with the discriminatory approach taken to non-Muslim citizens being evident in articles 3 and 4 of the current Constitution. Such discrimination exists not only in the Constitution, rather it is exists in a number key Afghan laws, combining to excessively restrict the political participation of Hindus and Sikhs, as well as affecting their public liberties, personal status, freedom of speech, freedom of religion and equal rights in the judicial system. This statutory discrimination is replicated in society where Hindus and Sikhs continue to face many challenges in their day-to-day lives.

The deprivation of the rights of Hindus and Sikhs has a long and strong root in Afghanistan and there has been little call for change to end this discrimination. Under Afghanistan's partial laws, Hindus and Sikhs were not able to be a member of parliament and a minister. Likewise, Afghanistan's current legal system is not an equalizing mechanism, rather is an assortment of legal contradictions and differentiations, as the current Constitution and laws continue to restrict and limit Afghan Hindus and Sikhs from being president, deputy president, a member of the Supreme Court or a judge. Until recently, Hindus and Sikhs could only be witnesses in court if they took an Islamic oath on the Qur'an.

In the public sphere Hindus and Sikhs continue to suffer from the structural suppression of the Islamic dominated mentality and are threatened by different types of violence. Hindus and Sikhs do not benefit from equal rights alongside Muslim citizens. Such suppression goes a long way back in a heinous history where they were socially labeled and forced to pay tax for being nonMuslims in an Islamic state.

The real face of legal discrimination against Hindus and Sikhs appears in the judiciary and justice system where the cases of personal status of Hindus and Sikhs are treated on the basis of Islamic Sharia Law. No such defined code exists for the Hindu and Sikh communities and does not appear to have been considered, despite the strong human rights rhetoric in the preamble and article 7 of the Constitution. Although human rights have featured in Afghanistan's constitutions since the 1964 Constitution, their implementation has failed. Even the current Constitution and 
laws read like religious edicts that ignore the rights of non-Muslim Afghan citizens like the Hindus and Sikhs.

Afghanistan's legal system has been excessively ritualized by Islamic thought, particularly by the more traditional and highly fundamental religious values, to the detriment of the human rights and equal participation in Afghan society of non-Muslim minorities such as Hindus and Sikhs.

\section{Recommendations}

- The international community should work with the Government of Afghanistan to reform its legal system and Constitution to provide greater safeguards for religious minorities and human rights.

- The international community should urge the Government of Afghanistan to protect religious minorities from violence and discrimination.

- The Government of Afghanistan should revise particular articles in the Constitution and other laws which suppress Hindus and Sikhs and limit their political participation, public liberties, freedom of religion and speech and violate their rights in the judicial system, so that these provisions align with human rights values.

- The Government of Afghanistan should ensure a unified and fair legal system by removing the religious monopoly on the legal system.

- The Government of Afghanistan should develop a personal status law for the Hindu and Sikh communities.

- Afghanistan Civil Society should propagate, problematize and debate the rights of suppressed groups and religious minorities. 


\section{References}

1) Leo, L. and Lantos Swett, K. (2012). Religious-Freedom Violations in South Asia | JIA SIPA. [online] Jia.sipa.columbia.edu. Available at:

http://jia.sipa.columbia.edu/online-articles/religious-freedom-violations-southasia/ [Accessed 11 Oct. 2016].

2) Hafsite.org. (2012). Afghanistan Policy Brief 2011-2012 | Hindu American Foundation (HAF). [online] Available at:

http://www.hafsite.org/media/pr/afghanistan-policy-brief-2011-2012 [Accessed 6 Oct. 2016].

3) Reuters. (2016). Afghanistan's dwindling Sikh, Hindu communities flee new abuses. [online] Available at: http://www.reuters.com/article/us-afghanistanminority-idUSKCN0Z82SL [Accessed 8 Oct. 2016].

4) Bureau of Democracy, Human Rights, and Labor, (2010). International Religious Freedom Report 2010. [online] U.S DEPARTMENT of STATE, p.208. Available at: http://www.state.gov/j/drl/rls/irf/2010/148786.htm [Accessed 11 Oct. 2016].

5) Bureau of Democracy, Human Rights, and Labor, (2012). Bureau of Democracy, Human Rights, and Labor. [online] U.S DEPARTMENT of STATE. Available at: http://www.state.gov/j/drl/rls/irf/2011/sca/192917.htm [Accessed 11 Oct. 2016].

6) Emadi, H. (2013). Minorities and marginality: pertinacity of Hindus and Sikhs in a repressive environment in Afghanistan. Nationalities Papers, 42(2), pp.307-320.

7) www.hafsite.org. (2012). Hindu American Foundation www.HAFsite.org Promoting Understanding, Tolerance and Pluralism Islamic Republic of Afghanistan Policy Brief: 2011 - 2012. [online] Available at: http://(www.hafsite.org/media/pr/afghanistan-policy-brief-2011-2012). [Accessed 1 Oct. 2016].

8) Islamic Republic of Afghanistan Ministry of Justice Chief Office of the Minister Human Rights Support Unit, (2012). Brief rep ort on reflection of Declaration on the Rights of Persons Belonging to National or Ethnic, Religious and Linguistic Minorities in national laws and its implementation in practice October November 2012. [online] Ministry of Justice. Available at: http://mojhrsu.gov.af/publication/menu/Brief_Report_Minorities_Rights.pdf [Accessed 11 Oct. 2016].

9) Pike, J. (2012). Afghanistan - Religion. [online] Globalsecurity.org. Available at: http://www.globalsecurity.org/military/world/afghanistan/religion.htm [Accessed 11 Oct. 2016].

10) Swett, K. and Leo, L. (2012). Religious-Freedom Violations in South Asia. JIA SIPA.

11) United States Department of State, (2011). International Religious Freedom Report for 2011. Bureau of Democracy, Human Rights and Labor.

12) United States Department of State, (2010). 2010 Report on International Religious Freedom. U.S. Department of State, p.208.

13) Bureau of Democracy, Human Rights and Labor, (2012). International Religious Freedom Report for 2012. U.S DEPARTMENT of STATE, p.3.7.

14) Bureau of Democracy, Human Rights and Labor, (2016). International Religious Freedom Report for 2012. U.S DEPARTMENT of STATE. 
15) Bureau of Democracy, Human Rights and Labor, (2013). AFGHANISTAN 2013 INTERNATIONAL RELIGIOUS FREEDOM REPORT. [online] U.S DEPARTMENT of STATE. Available at: http://www.state.gov/documents/organization/222535.pdf [Accessed 11 Oct. 2016].

16) Bureau of Democracy, Human Rights and Labor (2011). International Religious Freedom Report for 2011. U.S DEPARTMENT of STATE.pp.1.2.5.

17) USCIRF, (2014). [online] Available at: http://www.uscirf.gov/sites/default/files/Afghanistan\%202014.pdf [Accessed 9 Oct. 2016].

18) Moj.gov.af. (2016). [online] Available at: http://moj.gov.af/fa [Accessed 2 Nov. 2016].

19) Habermas, J. (2001). Globalization and Future of Democracy: Postnational Constellation. Trans. K, Poladi.Tehran: Markaz, pp.164,186.

20) Ministry of Justice, (1976). Civil Law. Kabul: Ministry of Justice p.1.

21) Ministry of Justice, (2005). Law on Structure and Authority of Courts of Judicial Body, Kabul: Ministry of Justice, p.46.

22) Ministry of Justice, (2003). Temporary Criminal Procedure Code. Kabul: Ministry of Justice, p.23.

23) Ministry of Justice, (2010). Military Criminal Procedure Code. Kabul: Ministry of Justice.

24) Ministry of Justice, (2014). Criminal Procedure Code. Kabul: Ministry of Justice. 